\title{
LETTER TO THE EDITOR
}

\section{THE PREVALENCE OF HIV-ANTIBODY IN A GOLD MINING CAMP IN THE AMAZON REGION AS A GUIDE TO THE DATE OF ENTRY OF AIDS INTO BRAZIL: THE FUTURE IMPORTANCE OF SUCH COMMUNITIES AS “DISTRIBUTION CENTRES"}

We have recently tested for the presence of HIV-antibody 250 serum samples collected in 1983, during a measles epidemic among gold $\mathrm{mi}$ ners encamped in the "Serra Pelada", Pará Sta te, north Brazil: at the time the population was all male, with ages ranging from $17-38$ years. Most of the men had come from other parts of Brazil, including the southeastern region - where the first cases of AIDS in this country were registered, in $1982^{2}$. There was a high rate of both homosexuality and prostitution in and around the camp.

All the serum specimens proved negative for HIV-antibody, using the Wellcozyme "kit" - a test which is basically an enzyme-linked immu nosorbent competitive assay ${ }^{1}$.

In view of the fact that a high proportion of the miners were from southeast regions, we feel that the total absence of HIV-antibody in this promiscuous population indicates that AIDS was just establishing itself in Brazil in 1983.

Other surveys for HIV-antibody in the same and additional mining-camps in the Amazon Region have been planned. They may show a very different epidemiological picture now, following the escalating incidence of AIDS in Brazil ${ }^{3}$ since that time. Apart from the high rate of homose- xuality and prostitution in such communities, there is an added hazard in the use of nondisposable syringes for administering medicines (even antimalarial drugs) among the miners.

Finally, in an area normally of low population and, therefore, low dissemination of AIDS, these mining camps (and other all-male workcamps) will undoubtedly serve as "distribution centres" for AIDS in Amazonia, Brazil.

\section{A. C. LINHARES Instituto Evandro Chagas, and FSESP,}

Wyller A. MELLO Av. Almirante Barroso, 492, CP 1128 , 66.050, Belém, Pará, Brasil

\section{REFERENCES}

1. EVANS, R. P.; SHANSON, D. C. \& MORTIMER, P. P. Clinical evaluation of Abbott and Wellcozyme enzyme-lin ked immunosorbent assays for detection of serum antibo dies to human immunodeficiency virus (H.I.V.). J. clin. Path., 40: 552-555, 1987.

2. MINISTERIO DA SAÚDE. Boletim Epidemiológico AIDS Ano 1, n: 01, semana epidemiológica, 26-30, 1987.

3. MINISTÉRIO DA SAÚDE. Boletim Epidemiológico AIDS. Ano I, n: 06, semana epidemiológica, 48-52, 1987.

Recebido para publicação em 16/11/1988. 